\title{
Sensitivity of Process Design due to Uncertainties in Property Estimates
}

\author{
Hukkerikar, Amol; Jones, Mark Nicholas; Sarup, Bent; Abildskov, Jens; Sin, Gürkan; Gani, Rafiqul
}

Published in:

Proceedings of the 11th International Symposium on Process Systems Engineering

Publication date:

2012

Document Version

Publisher's PDF, also known as Version of record

Link back to DTU Orbit

Citation (APA):

Hukkerikar, A., Jones, M. N., Sarup, B., Abildskov, J., Sin, G., \& Gani, R. (2012). Sensitivity of Process Design due to Uncertainties in Property Estimates. In I. A. Karimi, \& R. Srinivasan (Eds.), Proceedings of the 11th International Symposium on Process Systems Engineering (pp. 200-204). Elsevier. Computer Aided Chemical Engineering Vol. 31

\section{General rights}

Copyright and moral rights for the publications made accessible in the public portal are retained by the authors and/or other copyright owners and it is a condition of accessing publications that users recognise and abide by the legal requirements associated with these rights.

- Users may download and print one copy of any publication from the public portal for the purpose of private study or research.

- You may not further distribute the material or use it for any profit-making activity or commercial gain

- You may freely distribute the URL identifying the publication in the public portal 


\title{
Sensitivity of Process Design to Uncertainties in Property Estimates
}

\author{
Amol Hukkerikar ${ }^{\mathrm{a}}$, Mark Jones ${ }^{\mathrm{b}}$, Bent Sarup $^{\mathrm{c}}$, Jens Abildskov ${ }^{\mathrm{a}}$, Gürkan Sin $^{\mathrm{a}}$, Rafiqul Gani ${ }^{\mathrm{*}}$ \\ ${ }^{a}$ Computer Aided Process-Product Engineering Center (CAPEC), Department of Chemical and Biochemical \\ Engineering, Technical University of Denmark, DK-2800, kgs.Lyngby, Denmark. \\ ${ }^{\mathrm{b}}$ Department of Chemical Engineering, Technical University of Karlsruhe, Germany. \\ c Vegetable Oil Technology Business Unit, Alfa Laval Copenhagen A/S, Maskinvej 5, DK-2860, Soeborg, \\ Denmark.
}

Chemical process design involves determination of design parameters, such as, reactor volume, number of stages or heat/mass transfer areas in order to meet desired specifications, such as, conversion, product purity, or cost effectiveness. The accuracy and reliability of obtained design parameters largely depends on the accuracy of physical and thermodynamic property data and property prediction models employed. While use of experimentally measured values for the needed properties is desirable in process design, the experimental data for the properties of interest may not be available in many cases. Also, process design involving new molecules/mixtures require property models to be predictive. In such cases, predictive property estimation methods such as group contribution (GC) methods are generally suitable to obtain the needed property values. In addition to the accuracy of the property estimates, the process design engineer also requires to consider uncertainties in the estimated property values in order to assess the quality and reliability of the final design. As a consequence, efficient and reliable property prediction methods together with tools that can provide estimates of uncertainties in the estimated property values become vital pre-requisites to analyze and understand the sensitivity of process design to the effects of input uncertainties.

The objective of this work is to develop a systematic methodology for performing analysis of the sensitivity of process design to uncertainties in property estimates to help achieve robust process design as well as to establish acceptable levels of accuracy for different thermo-physical property prediction methods. The developed methodology includes: (i) collection of design input data and pure component property values estimated with a GC-method together with uncertainties in property estimates using a tool that employs maximum likelihood theory for predicting errors in property estimates; (ii) model construction, solution, verification and validation using modeling and simulation tools; and (iii) analysis of the sensitivity of the final design parameters to uncertainties in pure component property estimates using one-factor-at-a-time sensitivity analysis. The methodology was applied to evaluate the effects of uncertainties in thermo-physical property estimates on the design of different unit operations such as extractive distillation, short path evaporator, equilibrium reactor, liquid-liquid extraction and crystallizer. For unit operations involving vapor-liquid equilibria, different Gibbs Energy (GE) based models (NRTL, Wilson, UNIQUAC and UNIFAC) and Equation of State based models (SRK and PR) were considered in sensitivity analysis and for comparison of final design parameters obtained from different models. The results showed that depending on the chemical systems involved, the driving forces they represented, the operating conditions and the choice of the thermodynamic model for property prediction, the input uncertainties resulted in significant uncertainties in final design. The developed methodology was able to assess the quality of final design, to identify the pure component and mixture properties of critical importance from process design point-of-view, to identify additional experimentation needs to reduce the most critical uncertainties and to establish the acceptable quality of physical and thermodynamic property data and property prediction models that can provide them. 